\title{
A Cultural Political Economy of Legal Regulation of Monopoly and Competition Bob Jessop
}

This article is part of a review symposium on Brett Christophers, The Great Leveler: (2016) is a pre-copyedited version of an article in Environment \& Planning $A$ (in press) DOI: $0.1177 / 0308518 \times 16664092$

In this excellent book Brett Christophers offers an intriguing, historically-informed but partially inadequate response to a significant deficit in the regulationist analysis of political economy. Regulationists ask why, despite its inherent contradictions and crisis-tendencies, capital accumulation proceeds relatively smoothly for significant periods in specific spatio-temporal settings. They explain this through the trial-anderror emergence and consolidation of specific growth regimes and corresponding modes of régulation-cum-governance that, together, create complementary institutional forms and social norms and values that facilitate the integration of different circuits of capital and the development of a workable social compromise. Christophers notes correctly that regulationists often neglect the role of law, litigation, and judicial decision-making in securing this improbable result. This deficit is unfortunate because, as he rightly claims, law has a key role in modulating the balance between simultaneous tendencies to competition and monopoly in 'capitalist regimes of profitability and growth'. He then explores this topic in two steps: a theoretical account of the complex dialectics of competition and monopoly that frames detailed studies of three successive periods in the development of anti-trust law, which aims to limit monopoly in favour of competition, and of intellectual property rights (IPRs), which are intended to fashion and protect monopoly (2016: 4).

For Christophers, this framing is co-constitutive of the overall argument, with the conceptual and historical analysis, theory and empirics, being thoroughly intertwined (2016: 21-22). Yet Part l's broad analysis of competition and monopoly does not lead directly to the more detailed propositions and findings in Part II. In addressing this anomaly, I will first identify some internal theoretical problems and critique the flawed metaphor of balance between competition and monopoly developed in Part I. The key to my critique is that the world is too complex to be fully intelligible in real time, forcing simplifications as a way of 'going on' within it. In general competition occurs 
horizontally and vertically over various sites and scales and in increasingly complex and fractal ways, involves changing hierarchies of markets that set the parameters of competition, rests on different forms of political as well as market-mediated competition, divides and unites capitals as 'hostile brothers' depending on the kinds and sources of competition, and has important extra-economic as well economic aspects (see, for example, Karuma 1973; Harvey 1982; Wheelock 1983; Perelman 1987; Gough 1992; Moseley 2002; Jessop 2010). I then consider the case studies and suggest how to reconcile the broader problem of relating the dialectic between competition and monopoly to the empirics presented in the subsequent historical analysis. Specifically, I propose an alternative account that draws on cultural political economy and reveals more fully the significance of the case studies for differential accumulation (on cultural political economy, see Sum and Jessop 2013).

\section{The Great Leveler}

The book's title refers to the always challenging and constantly changing role of the legal order in maintaining the right conditions for capital accumulation. Specifically, Christophers argues that capitalism involves a dialectical relation between competition and monopoly, that it requires an appropriate balance between them, that their relative weight changes over time in line with different capitalist regimes, that this balance is not always present, and that law can correct imbalances. These claims are developed in the first part of the text and raise problems of exegesis, eclecticism, and theoretical consistency. I address these issues in this section of the commentary and then, assuming the validity of these claims for the sake of the next step in my critique, question their connection in section two before offering an alternative account in the third section.

On exegesis, Christophers argues that it is inadequate to figure competition, as he asserts that Marx does, as a mere passive 'executor; of relations established exclusively by productive forces (2016: 105). He then suggests that this 'productivist' bias leads Marx to underplay the importance of markets, exchange relations and market forces. Yet Marx is quite explicit that the law of value operates through the allocation of capital among alternative investments in different economic spheres (commercial, industrial, financial, and so on) and across space-time according to 
expectations of profit based on the anticipated difference between production prices and market prices. Thus the law of value already integrates circulation, distribution, and exchange and, a fortiori, market relations and market forces into the heart of the process of competition. Marx adds that it is through the configuration and operation of markets that surplus-value is distributed among profits of enterprise, interest, rent, and, one might add, IP payments (see Marx 1976a, 1976b; Mandel 1976: 41-2).

Moreover, despite Christophers's assertions, Marx does not treat competition and monopoly in general terms as equivalent and antithetical tendencies that should or could be balanced. Admittedly, there is rhetorical evidence for this in The Poverty of Philosophy (Marx 1976c: 195-6) and an earlier, related letter from Marx to Pavel Annenkov (cited by Christophers 2016: 51); Marx likewise observes in Capital that, in competition, one capitalist kills many (referring mainly here to the centralization of capital) (Marx 1976a: 714). However, Capital attends far more to competition as the expression of the inner nature of the capital relation than to its concentration or centralization. This may be because, as Marx notes, where centralization leads to super-profits, the law of value tends to direct capital into areas with above-average profits, which will then be competed away - unless natural or artificial monopolies exist, which will in turn create incentives to innovate to circumvent entrenched monopoly positions (there is an obvious overlap with Schumpeter here). Moreover, apart from some additions from Engels in Volume 3, Capital hardly discusses monopoly capital, cartels, or trusts; and, where Marx himself does discuss monopoly, he focuses mostly on land ownership and ground-rent and, for other types of capital, on technological monopolies rather than those based on organizational forms.

Marx's contributions to the study of industrial and intellectual property are largely ignored here as elsewhere. Yet he had a sophisticated account of their contradictory role in accumulation, especially in the equalization of profit rates among different kinds of capital producing different kinds of material and immaterial commodities and in the facilitation of super-profits deriving from IP-based rents. The balance between these effects depends once again on the operation of the law of value (for a reconstruction and extension, see Jessop 2004).

I emphasize these points not just for the sake of exegetical accuracy but because, if 
one takes Marx seriously (as Christophers does), the law of value is an important entry-point for analysing the dialectic of competition and monopoly, the context in which the state and law operate, and some potential limitations of juridico-political intervention in facilitating capital accumulation. This should be included among the 'conceptual first principles' (2016: 267) that organize and explain the case studies. Yet, after a brief appearance in Part I, it no longer figures in The Great Leveler and is replaced by comparative economic history and narrative policy analysis and general assertions about imbalances between competition and monopoly in different periods.

Another set of theoretical problems is rooted in the eclectic range of orthodox and heterodox sources employed in the account of competition and monopoly. Because these sources advance different analyses of competition and monopoly, their dynamic and articulation, and their consequences, this reinforces the theoretical problem of establishing the 'right' balance between them as a basis for undertaking historical research. Thus it is no surprise that Christophers does not provide an index of balance for capitalism as a whole or an indication of the spatiotemporal horizons over which it is to be judged (whether 'objectively' or in a court of law). Of course, this may be irrelevant in the real world, where other theoretical and policy paradigms and related economic imaginaries may be in play. But such a response would call into question the intertwining of the conceptual and historical analysis, theory and empirics. A potential post-hoc functionalist escape route here is the suggestion that serious imbalances are revealed in and through crises and that the law (anti-trust, IP, or both) is then mobilized to successfully restore the balance in line with the revealed needs of capital in a given crisis conjuncture (Christophers 2016: $21 \mathrm{ff}$ ).

This suggestion is also problematic. First, the crises mentioned in Part II are particular events (such as 'Black Tuesday' on 29 October 1929) but protracted periods marked by allegedly pathological symptoms (such as the 'First Great Depression'), widespread worries about the future effects of currently perceived imbalances (excessive monopoly power after 1945), or signs of declining national competitiveness (for example, the US economy from the 1980s onwards). Second, not only might one contest the depiction of these protracted periods as 'crises' but, if this portrayal were conceded, one would still face serious challenges in retroducing underlying causes and, hence, of knowing how to address them (on this topic, see Jessop 2015). Third, 
as the case studies show, competition and IP law also fail in crucial respects and, hence, there is no guarantee that they can serve the functions attributed to them alone, in combination, or in conjunction with yet other measures.

\section{The Limits of Law in Regulating Competition and Monopoly}

In Marxian terms, one rationale for attempts to rebalance monopoly and competition concerns a tension between (1) the interests of particular capitals in securing above average rates of profit at the expense of other capitals by engaging in anti-competitive forms of competition, such as through cartels or monopolies, and (2) the interest of capital in general in securing the free play of market forces so that no particular capitals are disadvantaged (cf. Christophers 2016: 167). This also holds for IPRs (cf. Christophers 2016: 111-18, 134). It is such tensions that competition and IP law are expected (cognitively or normatively) to resolve in different ways with important pathdependent contrasts between US anti-trust law and Continental European competition law and different attitudes towards intellectual property in advanced and developing economies (cf. Christophers 2016: 144-5).

While, following the work of Marx and Schumpeter, Christophers notes that competition promotes monopoly and creative destruction, in contrast to these authors he focuses on competition in market price formation and exchange relations. This sidelines the broader operation of the law of value and, for Schumpeter, the role of long wave dynamics in transforming growth regimes. This focus on market prices reflects the concerns of classical political economy and the neo-classical tradition as well as legal scholarship and practice. The result is to underplay theoretically and empirically the limits of competition law in regulating the balance between competition and monopoly. It is easier to regulate monopolies and anti-competitive competition in market exchange (manipulating market prices) than it is to regulate anti-competitive competition in the productive sphere that is grounded in, for example, technological monopolies or innovation (Jessop 2013). Indeed, where competitiveness stems from more effective capacities to reduce socially necessary labour times, turnover times and the times of natural reproduction, it can generate super-profits for a time even when commodities are sold at or below 'normal' market prices. This is more likely during intense periods of creative destruction (Schumpeter 1962). Such transitions 
tend to disrupt competition law, which lags behind changes in products, processes, marketing, sourcing, and corporate organization. In addition, many kinds of competitive and anti-competitive behavior remain beyond the reach of competition law because they are beyond its remit (e.g., non-tariff trade barriers or the activities of the competition state) and this, in turn, sets limits to the capacity of law to find the right balance between monopoly and competition in price formation.

Christophers presents a stronger case for getting the competition-monopoly balance right in the field of IPRs as an aspect of market power. Yet this has 'ineluctable implications for the productive sphere given the aforementioned "dynamic totality" nature of capital' (2016: 113). But he also shows that this balance mainly concerns that between monopoly (hoarding) and dissemination rather than between monopoly and competition (2016:111-12, 269-70). Once again this indicates the complexities of the dialectic between competition and monopoly and its analytical challenges.

\section{A Cultural Political Economy Perspective}

The complexities of capital accumulation on a world scale are so great that an 'appropriate balance' between competition and monopoly is unknowable even with hindsight, especially given the problem of counterfactuals. This is problematic even for the balance between competition law and IPR law, let alone for the overall balance between competition and monopoly in all their diverse, dialectically intertwined, and often only analytically separable, forms .Indeed, even the notion of balance is misleading insofar as it implies an equilibrium or equilibration process between two opposing forces (the same holds for the author's metaphor of a legal pendulum swinging too far to one side or another before coming to a temporary rest) (Christophers 2016: 214, 244). This means that any judgement on how to strike the right balance between competition and monopoly (or their legal aspects) and their proper place in accumulation, the distribution of profits, and growth dynamics will depend on socially constructed imaginaries rather than some objective criterion.

These imaginaries vary with competing economic, political, legal and social imaginaries and any corresponding policy paradigms. They also vary with the interests and perspectives of different capitals and fractions, the changing balance between 
capital and labour, the preferences of rival political forces, and competing traditions and schools of economics and law. Among the main forces involved in such efforts identified in The Great Leveler are: powerful business interests, small business, farmers, organized labour, consumers, economists, academic lawyers, the judiciary, the state, international economic agencies such as the WTO (via TRIPS), the press, social and political currents such as the Progressive movement, and neoliberal think tanks such as the Mont Pelerin Society. Other influences are fundamental legalphilosophical paradigms, economic and legal doctrines, intellectual sea changes, protectionism, laissez-faire, military contingencies, war-time patriotism, and shared class values. This opens space for a great deal of contingency. Yet the resulting laws, judicial decisions, legal innovations, and legal practices cannot be purely 'arbitrary, rationalistic and willed' (Gramsci 1971: 376-7) if they are to secure the right balance between competition and monopoly for 'healthy' ( $\operatorname{sic}$ ) accumulation or restore it in the face of acute or chronic crises. On the contrary, they must have some significant, albeit necessarily partial, correspondence to real material interdependencies in the actually existing economy and/or in relations between economic and extra-economic activities.

Thus an alternative entry-point is to ask why some imaginaries and paradigms come to be selected in a specific conjuncture, get translated into law and judicial decisions or state interventions, and why some of these work well enough to support the next stage of expansion before new tensions, conflicts, and crises indicate a need for a new balance. This requires attention to the various mechanisms that operate to select and retain some economic and legal imaginaries, some sets of economic interests, some crisis diagnoses, and some policy paradigms rather than others. We need more detailed analyses about which construals regarding the right balance between competition and monopoly were excluded, which policies were then tried and failed, and about the constitutive or performative effects of legal solutions. Relevant to this process of variation, selection and retention are discursive, structural, technological (in the Foucauldian sense of governmentality), and agential mechanisms (Sum and Jessop 2013). Such analyses may also help to explain the differences between the United Kingdom and United States, the leads and lags between economic and legal development during prolonged crises and transition periods, and the changing scales and scope of legal regulation and the governance of monopoly and competition. Many 
of these intertwined issues surface in the case studies and invite further theoretical and empirical investigation.

\section{Conclusions}

It should be evident from this and other contributions to this symposium that Brett Christophers has produced a well-researched and provocative book that identifies a major gap in heterodox political economy and synthesizes a huge amount of theoretical and historical material. I will not repeat my criticisms here. Instead I suggest that a more appropriate metaphor than the (im)balance between two opposing forces might be a parallelogram of multiple causal mechanisms and counter-mechanisms, tendencies and counter-tendencies, that develop unevenly in space-time and present different challenges at different moments for different agents such that there is no 'onesize-fits-all' best solution, let alone a stable, if temporary, point of rest. In turn, this suggests a much more complex process than equilibration, namely, collibration, which involves the continuing trial-and-error task of governing this changing parallelogram of forces through diverse strategies and mechanisms. Law, litigation, and judicial decision-making would then become part of a repertoire of resources and their role in competing efforts at collibration would be seen as contested and contingent rather than governed quasi-teleologically by the 'needs' of capital for the right balance between competition and monopoly in any given period.

\section{References}

Christophers B (2016) The Great Leveler: Capitalism and Competition in the Court of Law. Cambridge, MA: Harvard University Press.

Gough J (1992) Workers' competition, class relations, and space. Environment and

Planning D: Society and Space 10(3): 265-286.

Gramsci A (1971) Selections from the Prison Notebooks. London: Lawrence \& Wishart.

Harvey D (1982) The Limits to Capital. Oxford: Blackwell.

Jessop B (2004) Intellektuelle Eigentumsrechte [intellectual property rights]. In: FW Haug (ed.) Historisch Kritisches Wörterbuch des Marxismus, Berlin: Argument, vol. 6(2), pp. 1287-95. 
Jessop B (2010) Konkurrenz [competition]. In: FW Haug (ed.) Historisch Kritisches Wörterbuch des Marxismus, Berlin: Argument, vol. 7(2), pp. 1542-1564.

Jessop B (2013) The complexities of competition and competitiveness: challenges for competition law and economic governance in variegated capitalism. In: MW Dowdle, J Gillespie, and I Maher (eds) Asian Capitalism and the Regulation of Competition. New York: Cambridge University Press, pp. 96-120.

Jessop B (2015) The symptomatology of crises: reading crises and learning from them. Journal of Critical Realism 14(3): 238-271.

Karuma S (1973) Marx-Lexikon zur politischen Ökonomie, Band 1. Konkurrenz. Glashüten im Taunus: Detlev Auvermann.

Mandel E (1976) Introduction. In: K Marx, Capital. Volume I. Harmondsworth: Penguin, pp. 11-86.

Marx K (1976a) Capital. Volume I. London: Lawrence \& Wishart.

Marx K (1976b) Capital. Volume III. London: Lawrence \& Wishart.

Marx K (1976c) The Poverty of Philosophy. In: Marx and Engels Collected Works, vol. 6. London: Lawrence \& Wishart, pp. 105-212.

Moseley F (2002) Hostile brothers: Marx's theory of the distribution of surplus-value in Volume 3 of Capital. In: G Reuten and M Williams (eds) The Culmination of Capital. Basingstoke: Palgrave-Macmillan, pp. 65-101.

Perelman M (1987) Marx's Crises Theory: Labor, Scarcity, Finance. New York: Praeger.

Schumpeter JA (1962) Theory of Economic Development. Boston: Harvard University Press.

Sum N and Jessop B (2013) Towards a Cultural Political Economy: Putting Culture in its Place in Political Economy. Cheltenham: Elgar.

Wheelock J (1983) Competition in the Marxist tradition. Capital \& Class 21: 18-47. 